\title{
Academic Self-Efficacy of High Achieving Students in Mexico
}

\author{
Ana Karen Camelo-Lavadores ${ }^{1}$, Pedro Sánchez-Escobedo ${ }^{1, *} \&$ Jesus Pinto-Sosa ${ }^{1}$ \\ ${ }^{1}$ Facultad de Educación, Universidad Autónoma de Yucatán, Mexico \\ *Correspondence: Facultad de Educacion, Universidad Autónoma de Yucatán Mexico. 39A n. 376 x28 y 30 Merida \\ Yuc 97114, Mexico. Tel: 521-9999-947-8681. E-mail: psanchez@correo.uady.mx
}

Received: Augusut 31, 2017

Accepted: September 11, 2017 Online Published: September 26, 2017

doi:10.5430/jct.v6n2p84

URL: https://doi.org/10.5430/jct.v6n2p84

\begin{abstract}
The purpose of this study was to explore for differences in the academic self-efficacy of Mexican high school students. A gird questionnaire was administered to 1,460 students form private and public schools. As expected, high achieving students showed significantly higher academic self-efficacy that their peers. However, interesting gender differences were found. Whereas men had higher self-efficacy feelings towards Math, Sciences and English as a second language; women showed higher self-efficacy in Spanish language. Likewise, private school's students showed feelings of academic self-efficacy. Implications of findings for education practice and research are discussed.
\end{abstract}

Keywords: high achieving students; self-efficacy; academic self-efficacy

\section{Introduction}

\subsection{Studying High Achieving Students}

Farkas, Duffett y Loveless (2008) assert that meanwhile schools make efforts to improve the academic performance of the students with learning difficulties, their resources rarely converge in the necessities of the students showing high achievement. They argue that, in general, training programs do not prepare future teachers to work with high achievers and gifted students. Shayshon, Gal, Tesler y Ko (2014) demonstrated that teachers, when addressing high achieving students, do minor modifications to their teaching techniques and they carry out little adaptations to the curriculum in response to their needs and demands in the classroom.

Likewise, research on high achieving students in Mexico and in Latin America, in general, is scarce; since teacher assume that these students require little academic support and present fewer problems than regular students. The purpose of this study is to explore difference between academic self-efficacy feelings of high achieving and regular high school students in Mexico.

Regarding high achieving students, educational research results have yielded ambiguous results. Whereas some authors underline the respect and high regard of peers, others stress the social rejection and stigmatization of high achieving students.

For example, whilst Händel, Vialle, \& Ziegler (2013) discovered negative reactions of peers of high achieving students and social disapproval in the group, Manaster, Chan, Watt \& Wiehe (1994) found that talented students had positive social perception and they were respected by the group. However, they also reported that high achievement students were negatively labeled as nerds and so on.

In this regard, Rentzsch, Shütz, and Schröder-Abé (2011) described high achievers as intelligent students with high academic ambition driving to reach academic success and reported that their apparent "lack of modesty and high effort" were associated with dislike by their peers (p.160).

In fact, students with high levels of academic achievement are often subject to intense and continuous pressures to restrain their academic performance, and may lose motivation because of the social taxes associated to their academic success (Gross, 1989).

Stake y Nickens (2005) concluded that peers may negatively influence the student's self-image as future potential scientists.

Beyond peers, teacher perceptions are also important. Hughes, Dyer, Luo y Kwok (2009) suggested that teacher's 
praxis contributed to the positive academic reputation of high achieving students and that their opinions of good students influence other students' perception of competency. In fact, teachers play a vital role in helping high achieving students to adapt and succeed, not only in the academic life in but the personal one (Kesner, 2005). A positive teacher's perception has been positively correlated to the performance motivation in high school students (Wentzel, 1997).

Indeed, parents may also play a role in constructing feelings of academic self-efficacy in high achieving students since motivation to maintain such a high performance comes from their peers, teachers, parents, and other close to them (Wentzel, 1998). Finally, as Tourón, Fernández and Rayero (2002) assert parents and teachers alike are important to the high achieving child, because they opinion reflects into their daily behavior inside the classroom and their home.

\subsection{Academic Self-Efficacy}

Self-efficacy is a personal belief in one's capability to organize and execute a course of action required to attain mastery and succeed in specific tasks and it has been a key component in theories of motivation and learning in varied contexts.

This concept emerged from the seminal work of Bandura who posited that self -efficacy affects an individual's choice of activities, effort, and persistence. People who have low self-efficacy for accomplishing a specific task may avoid it, while those who believe they are capable are more likely to participate.

Artino (2012) claims that self- efficacy emerges from four primary sources: (a) enactive mastery experiences (actual performances); (b) observation of others (vicarious experiences); (c) forms of persuasion, both verbal and otherwise; and (d) physiological and affective states from which people partly judge their capableness, strength, and vulnerability to dysfunction.

In this work, we focus in academic self-efficacy as the portion of the self-concept construct related specifically to learning. Academic self-efficacy corresponds with pupils' explanations of their accomplishments and it is viewed as instrumental to academic achievement (Dickhäuser \& Steinmeier-Pelster, 2002).

Theoretically, high achieving students would be expected to have higher feelings of self-efficacy, but empirical evidence of this has been difficult to find, in spite that in the las 4 decades several educational researchers had used this concept to predict and explain a wide range educational phenomena from athletic skill to academic achievement.

Hardy (2014) claims that the study of self-efficacy may help teachers understand its underlying structure and the process through which academic self-concepts can be raised or lowered.

Marsh (1990) provided a theoretical perspective to explain how students develop self-efficacy feelings by using two different frames of reference to evaluate their abilities and achievements in different domains (mathematical subjects vs. verbal subjects). March argued that students differ on their feelings of academic self-efficacy by subject, and they are mainly based on the feedback they receive about their achievements (Marsh \& Shavelson, 1985).

Marsh (1990) also posted that Math and Verbal self-concepts are unrelated and independently developed with relation external and internal comparisons. Students compare their own math and verbal abilities with the perceived abilities of other students in their frame of reference.

Given the fact that self-efficacy is domain specific, in this research we address feelings of efficacy in four general educational domains: Spanish Language, English as a foreign language, Mathematics and Sciences.

\subsection{Grid Measures}

To establish degree of self-efficacy, we used an adaptation of Rost's (1993) grid measure since it has proven time effective and flexible. A grid allows to measure a given dimension or trait across various dimensions. There is also ample evidence of their reliability, validly and practical value in assessing a variety of psychological traits in school settings (Rost, Spartfeldt, Dickhauser, \& Schilling, 2005).

Instruments developed under the Grid measure logic, set several items evaluating a given construct. These items are organized in rows (stem) that are rated across diverse domains or subjects (columns), so the gird structure provides an economic measure to assess several dimensions with relation to the stem concept.

Rost kindly allowed us to review, translate and adapt his Differentiated School Self-Concept (DISC) Grid to develop the resultant Mexican Differentiate school academic self-efficacy Grid. 


\section{Method}

\subsection{Participants}

Participants were men and women from 14 to 19 years old, all high school students in the state of Yucatan Mexico. A total of 1,460 students voluntarily responded in complete fashion. They were from both public and private schools. Table 1 depicts the sample.

Table 1. Sample

\begin{tabular}{llccccc}
\hline & & 1 & 2 & 3 & Total & Percent \\
\hline Public & Men & 238 & 149 & 149 & 536 & 45 \\
& Women & 285 & 201 & 175 & 661 & 55 \\
Subtotal & & 523 & 350 & 324 & 1197 & 100 \\
Private & Men & 75 & 51 & 63 & 189 & 72 \\
& Women & 26 & 30 & 18 & 74 & 28 \\
Subtotal & & 101 & 81 & 81 & 263 & 100 \\
& Total & 624 & 431 & 405 & 1460 & 100 \\
\hline
\end{tabular}

The proportion of private public schools is consistent with the general Mexican high school population, and both sexes are represented within expected age ranges for this educational level. From this group 64 (4\%) students were identified as high achievers because they fulfilled two inclusion criteria: GPA scores over the 95 percentiles and being identified as a high achieving students by at least one teacher.

\subsection{Instrument}

The original version of the Differentiated School Self-Concept (DISC), was provided for analysis and translation. The purpose of this Grid is to assess scholastic self-perception of students, by asking some self-appraisal questions in relation to various academic subjects.

The DISK-Grid is an instrument with eight items. Each item forms one row; each discipline/subject (Math, Physics, German, and English) forms one column. The students are told to think about each subject independently and mark in a 7 point Likert scales their perception.

Translation to Spanish langue was derived from both English and German items. Back translations from both languages was also use. Final list of items was used to conform a similar scale as the original, changing the subject German for Spanish.

The translated and adapted version was administered to a sample of 106 high school students, from a school not included in the final study.

In general participant in this pilot study claimed that this measured self-perception regarding competencies in each of the subjects, and that their judgments tended to be different and independent per subject. However, a general complaint was the complexity of the instrument and the time I took to respond to that.

Feedback form this pilot stage, lead us to simplify the instrument for Mexican students by shortening the Likert scale from 7 to 5 points, reducing the number of steam items from eight to six.

\subsection{Data Analysis}

Responses were coded and a data bae created to be analyzed with various statistical software programs. The following section present results.

\section{Results}

Table 2 compares the self-efficacy feelings between the regular students (RS) and the high achieving students (HAS) per sex in a scale from 6 to 30 . 
Table 2. Self-Efficacy per Group

\begin{tabular}{lllll}
\hline & \multicolumn{2}{c}{ RS } & \multicolumn{2}{c}{ HAS } \\
\hline Subject & Men & Women & Men & Women \\
Math & 18.67 & 16.52 & $23.82^{*}$ & 21.02 \\
& $(5.82)$ & $(5.65)$ & $(4.99)$ & $(5.28)$ \\
Spanish & 20.03 & 21.00 & 23.06 & 22.02 \\
& $(4.70)$ & $(4.46)$ & $(4.56)$ & $(4.45)$ \\
Science & 19.92 & 19.11 & 23.20 & 21.26 \\
& $(5.32)$ & $(5.06)$ & $(5.06)$ & $(4.39)$ \\
English & 18.85 & 18.11 & $22.31^{*}$ & 19.23 \\
& $(6.58)$ & $(6.71)$ & $(7.17)$ & $(4.78)$ \\
\hline
\end{tabular}

* $\leq .05 . \mathrm{RS}=$ Regular students. HAS 0 High achieving students

As expected, self-efficacy feelings of HAS are significantly higher in every dimension.

In general, male students showed higher self-efficacy in Math, whereas women showed higher self-efficacy in Spanish language, but not in English as a second language.

Overall, findings show that Mexican men tend to have higher self-efficacy feelings than women, even though females had higher GPA than men (Men M: 94.32 SD: 1.82; Women M: 95.23, SD: 2.08).

Difference between private and public schools were also explored the self-efficacy feelings per subject in public and private schools. Table 3 , shows the results.

Table 3. Self-Efficacy per Type of School

\begin{tabular}{lll}
\hline Subject & School & \\
\cline { 2 - 3 } & Public & Private \\
\hline Math & 17.16 & $20.66^{*}$ \\
& $(5.73)$ & $(5.80)$ \\
Spanish & 20.43 & $21.41^{*}$ \\
& $(4.64)$ & $(4.45)$ \\
Science & 19.61 & 19.77 \\
& $(5.14)$ & $(5.53)$ \\
English & 17.97 & $21.41^{*}$ \\
& $(6.57)$ & $(6.25)$ \\
Total & 75.19 & $83.27^{*}$ \\
& $(14.17)$ & $(13.77)$ \\
\hline
\end{tabular}

$* \mathrm{p}=\leq .05$

Except in Sciences, students form private Mexican schools show significantly higher self-efficacy than public school students.

\section{Conclusion and Discussion}

Higher feelings of academic self-efficacy were empirically proven in high achievement Mexican students. In addition, interesting gender differences were found.

Men have higher self-efficacy feelings overall, and specifically in Math, Science and English as a second language. Participating women showed higher self-efficacy in Spanish (native) language. Results are consistent with other reports showing higher interest, achievement and self-efficacy in Math and Science of men and preference for language skills in women (Halpern, Benbow, \& Geary, 2007)

These findings are consistent with Lindberg et al (2010) study, who report men outperform women in mathematic tests, and this advantage rises with age.

Regarding the comparison between school type, private high school's students have higher academic self-efficacy feelings than students in a public one. This data may relate to the effects of better socioeconomic status (SES) and educational resources as several authors have suggested with relation to school achievement (Dewaele, 2007; Fichsbein, 1990; Undheim, 1992). In addition, parents making an effort to pay a private tuition my show as Voyer 
and Voyer (2014) suggested values and beliefs that "contribute to better school achievement in their children" (pág. 1176).

Results suggest that while testing differences in the self-efficacy of high achievers and regular or low achieving student's might be rather futile; exploring gender differences, types of schooling and self-efficacy in specific areas may yield valuable information for teachers and counselors alike. As Valdes, Sanchez y Yañez (2013) claimed, further research is neede3d to understand the school needs and assets of high achieving students in Mexico.

\section{References}

Artino, A. (2012). Academic self-efficacy: form educational theory to instrutional practice. Perspectives on medical Education, 76-85. https://doi.org/10.1007/s40037-012-0012-5

Dewaele, J. M. (2007). Predicting language learners' grades in the L1, L2, L3 and L4: The effect of some psychological and sociocognitive variables. International Journal of Multilinguism, 169-197. https://doi.org/10.2167/ijm080.0

Dickhäuser, O., \& Steinmeier-Pelster, J. (2002). Gender differences in computer work evidence for the model of achievement-related choices. Contemporary Educational Psychology, 486-496. https://doi.org/10.1006/ceps.2001.1106

Farkas, S., Duffett, A., \& Loveless, T. (2008). High-achieving students in the era of No Child Left Behind. Washington DC, USA: Thomas B. Fordham Institute.

Fichsbein, S. (1990). Biosocial influences on sex differences for ability and achievement test results as well as marks at school. Intelligence, 127-139.

Gross, M. (1989). The pursuit of excellence or the search for intimacy? The forced-choice dilemma of gifted youth. Roeper Review, 11(4), 189-194. https://doi.org/10.1080/02783198909553207

Halpern, D., Benbow, C., \& Geary, R. (2007, August). The Science of Sex Differences in Science and Mathematics. Psychol Sci Public Interest, 8(1), 1-51. https://doi.org/10.1111/j.1529-1006.2007.00032.x

Handel, M., Vialle, W., \& Ziegler, A. (2013). Student perceptions of high-achieving classmates. High Ability Studies, 24(2), 99-114. https://doi.org/10.1080/13598139.2013.843139

Hardy, G. (2014). Academic self-concept: modeling and measuring for Science. Res Scie Educ, 549-579. https://doi.org/10.1007/s11165-013-9393-7

Hughes, J., Dyer, N., Luo, W., \& Kwok, O. (2009). Effects of peer academic reputation on achievement in academically at-risk elementary students. Journal of Applied Developmental Psychology, 30(2), 183-194. https://doi.org/10.1016/j.appdev.2008.12.008

Kesner, J. (2005). Gifted children's relationships with teachers. International Education Journal, 6(2), 218-223.

Lindberg, S., Hyde, J., Petersen, J., \& Linn, M. (2010). New trends in gender and mathematics performance: a meta-analysis. Psychological Bulletin, 136, 1123-1135. https://doi.org/10.1037/a0021276

Manaster, G., Chan, J., Watt, C., \& Wiehe, J. (1994). Gifted adolescents' attitudes toward their giftedness: a partial replication . Gifted Child Quarterly, 38, 176-178. https://doi.org/10.1177/001698629403800404

Marsh, H. (1990). A multidimensional, hierarchical self-concept: theorethical and empirical justification. Educational Psychology Review, 77-172. https://doi.org/10.1007/BF01322177

Marsh, H., \& Shavelson, R. (1985). Self-concept:its multifaceted amnd hierarchical structure. Educational Psychologist, 107-125. https://doi.org/10.1207/s15326985ep2003_1

Rost, D., \& Lammfuss, S. (1993). Development of a short scale to measure self-concept pof academic performance and ability. The German Journal of Psychology, 151-152.

Rost, D., Spartfeldt, J., Dickhauser, O., \& Schilling, S. (2005). Dimensional comparisions in subject-specific academic self-concepts and achievements: a quasi-experimental approach. Learning and Instruction, 557-570. https://doi.org/10.1016/j.learninstruc.2005.08.003

Shayshon, B., Gal, H., Tesler, B., \& Ko, E. (2014). Teaching mathematically talented students: a cross-cultural study about their teachers' views. Educational Studies in Mathematics, 87, 409-438. https://doi.org/10.1007/s10649-014-9568-9 
Stake, J., \& Nickens, S. (2005). Adolescent girls' and boys' science peer relationships and perceptions of the possible self as scientist. Sex Roles, 52, 1-11. https://doi.org/10.1007/s11199-005-1189-4

Touron, J., Fernández, R., \& Reyero, M. (2002). Actitudes del profesorado hacia la superdotación. Implicaciones para el desarrollo de programas de formación. Faísca, 9, 95-110.

Undheim, J. (1992). Socio-economic factors and sex differences in an egalitarian educational system: academic achievement in 16 year-old Norwegian students. Scandinavian Journal of Educational Research, 87-98. https://doi.org/10.1080/0031383920360201

Valdés, A., Arreola, C., \& Montoya, G. (2012). Estado del arte de la investigación acerca de estudiantes con aptitudes sobresalientes en México. In A. Valdés, \& J. Vera(eds.), Estudiantes intelectualmente sobresalientes (pp. 156-170). Distrito Federal, México: Pearson.

Valdés, A., Sánchez, P., \& Yánez, A. (2013). Perfiles de estudiantes mexicanos con aptitudes intelectuales sobresalientes. Acta Colombiana de Psicología, 16(1), 25-33.

Voyer, D., \& Voyer, S. (2014). Gender differences in scholastic achievement: a meta-analysis. Psychological Bulletin, 140(4), 1174-1204. https://doi.org/10.1037/a0036620

Wentzel. (1998). Social Relationships and Motivation in Middle School: the role of parents, teachers, and peers. Journal of Educational Psychology, 90, 202-209. https://doi.org/10.1037/0022-0663.90.2.202

Wentzel, K. (1997). Student motivation in middle school: a role of perceived pedagogical caring. Journal of Educational Psychology, 89, 411-419. https://doi.org/10.1037/0022-0663.89.3.411 